\title{
Expression of a Chimeric Magainin Gene in Potato Confers Improved Resistance to the Phytopathogen Erwinia carotovora
}

\author{
Philippa J. Barrell* and Anthony J. Conner
}

\author{
New Zealand Institute for Plant \& Food Research Ltd, Private Bag 4704, Christchurch, New Zealand; and \\ Bio-Protection Research Centre, PO Box 84, Lincoln University, Canterbury, New Zealand
}

\begin{abstract}
Magainin peptides originally identified from Xenopus laevis have cytotoxic effects against a range of prokaryotic organisms without harmful effects on higher eukaryotes. The mechanism of cytotoxicity of the peptides is by disruption of membranes, which causes osmolysis. Magainin peptides are known to inhibit the in vitro growth of many phytopathogens including Erwinia carotovora, the causative agent of soft rot disease in potato. A synthetic gene was constructed based on the antimicrobial peptide magainin II. The coding sequence for the modified magainin II, magaininD, was constructed using potato codon preference. Modifications included a point mutation previously shown to reduce proteolytic cleavage, and three substitutions known to increase activity of the peptide against prokaryotic organisms. Agrobacteriummediated transformation was used to generate transgenic potato plants. Each line was tested for expression of the transgene at RNA and protein levels using RT-PCR and western analyses. Lines were identified that expressed both RNA and protein of the magaininD transgene. Field trials with the transgenic magaininD potato plants were conducted over three seasons, and harvested tubers were evaluated in bioassays for resistance to Erwinia carotovora ssp. atroseptica. Results from bioassays identified potato lines with significantly improved resistance to soft rot compared with control lines. The same lines were determined to have higher levels of expression of the transgene-derived peptide. The result demonstrated that the design, construction and transformation of a synthetic antimicrobial magainin gene was a successful strategy in introducing a novel form of disease resistance in potato plants.
\end{abstract}

Key Words: Potato, soft rot, Erwinia carotovora, transformation, antibacterial peptide, magainin, western, crop improvement.

\section{INTRODUCTION}

Bacterial diseases pose a significant threat to many crop species $[1,2]$. Despite the use of different crop protection measures including the use of agrochemicals, bacterial diseases in most cases are still able to cause serious damage to crop plants [3, 4]. The bacterial diseases of potato (Solanum tuberosum L.) known as "blackleg" and "soft rot" are caused by Erwinia carotovora. Blackleg commonly induces a black rot of the stem base and generally develops well after emergence [5]. Symptoms of soft rot are diverse, ranging from rot of the tubers, stem and leaves to stunting, wilting and desiccation of the plant and vascular browning [6]. Some difference in susceptibility to soft rot exists in potato cultivars according to cell wall content [7], but no potato genotype is known to be completely immune to the disease caused by soft rot bacteria. Traditional plant breeding for resistance to soft rot in potato has therefore been hampered through lack of appropriate resistant germplasm $[1,8]$.

The introduction of improved microbial disease resistance has been reported in transgenic plants expressing different antimicrobial peptides [e.g. 9-14]. One such peptide, magainin II from Xenopus laevis (African clawed frog) [15] has important properties for the engineering of transgenic

*Address correspondence to this author at the New Zealand Institute for Plant \& Food Research Ltd, Private Bag 4704, Christchurch, New Zealand;

E-mail: BarrellP@crop.cri.nz plants. Magainin peptides kill bacteria faster than the doubling time of many bacteria, which means peptide antibiotics may not face the rapid emergence of resistance in bacterial populations [16].

A general feature of antimicrobial peptides, including magainin peptides, is their broad range of activity against a number of phytopathogens, including fungi [17, 18]. The peptides have activity against the bacterial agents causing common scab (Streptomyces scabies), blackleg and tuber soft rot diseases of potato (E. carotovora) [19]. Alan and Earle [20] also investigated the efficacy of magainin II and a derivative of magainin II (MSI-99) against a range of bacteria (including E. caratovora) and fungi and found the peptides to be effective in killing the pathogens at similar concentrations.

Magainin peptides did not appear to be toxic to in vitro plant tissue [19]. No evidence for toxicity was observed toward potato cultivar Iwa on exposure to synthetic magainin I, magainin II and magainin II amide peptides at $37.5 \mu \mathrm{g} / \mathrm{mL}$, a concentration anticipated to accumulate from transgenederived expression in plant tissue [19]. DeGray et al. [14] expressed an analogue of magainin II (MSI-99) in the chloroplast genome of tobacco, and found no adverse effect on plant growth and development.

The mechanisms of action of magainin peptides are well studied [21, 22]. Importantly, magainin peptides are selectively toxic to microbes and not mammalian tissue. Magainin II does not lyse human erythrocytes [15], and was non-toxic when expressed as part of a haemoglobin gene in transgenic 
mice [23]. Magainin expressed as transgene-derived proteins would be expected to be highly labile and degraded rapidly after ingestion by higher eukaryotes, or in the soil environment, leaving no toxic residues [24]. Therefore, the production of these peptides in potato tissues is unlikely to pose a risk to human or animal health on ingestion.

Bacteria spread and multiply in the intercellular spaces when initiating disease infection of plants [25]. If a synthetic magainin gene could be synthesised with a signal sequence that directed the export of translated peptides into the intercellular space, the peptides could potentially kill microbes prior to entry into the cytoplasm and therefore be effective against bacterial cells.

Magainin peptides and derivatives have been reported to enhance resistance to phytopathogens in transgenic tobacco $[13,14]$, tomato [26], and banana [27]. However, none of those reports provided data on the detection of the expressed transgene-derived peptide.

We transformed potato with a synthetic gene encoding an analogue of magainin II, magaininD. The amino acid sequence of magaininD differed to magainin II with the incorporation of a His residue to Arg substitution, which was reported to increase the peptide's stability against protease cleavage [28]. Three Ala substitutions were also included that have been reported to result in increased antimicrobial activity of the peptide [29]. The coding sequence of magaininD was ligated into a chimeric expression construct directing export of the translated peptide into the intercellular space. We were able to detect the expression of the gene at the RNA level by RT-PCR, and provide the first report of detection of the expression of a transgenic magainin peptide from plants by western analysis. Three consecutive years of pathogen assays of field-grown transgenic potato tubers identified lines with improved resistance to Erwinia carotovora, and western analyses showed high levels of expression of the magaininD peptide in these resistant lines.

\section{MATERIALS AND METHODS}

\section{Vector Construction}

The magaininD amino acid sequence was modified from the published magainin II sequence [15] such that $\mathrm{His}^{7}, \mathrm{Ser}^{8}$, Gly $^{13}$ and Gly ${ }^{18}$ were modified to Arg, Ala, Ala and Ala respectively. Four separate but complementary and overlapping primers were used to construct the magainin DNA coding region. To increase the likelihood of translation, and make the genes "potato-like", the nucleotide sequence of the magainin gene was designed according to potato codon preference as described by Liew [30]. The primers were designed to incorporate a $S p h \mathrm{I}$ site at the 5' end and a BamHI site at the 3' end of the coding region, as follows: Primer 1: 5' ggggcatgccggaatcggaaaattttgcgtgcagctaaaaagtttg 3';
Primer 2: 5' caaaagcatttgttgcagaaattatgaactcataggatcccc 3'; Primer 3: 5' cccgtacggccttagccttttaaaaacgcacgtcgatttt 3'; Primer 4: 5' tcaaacgttttcgtaaacaacgtctttaatacttgagtatcctagggg 3'. Primers 1 and 3, and primers 2 and 4, were annealed; then both sets were ligated prior to digestion with Sph I and Bam HI. The digested fragment was ligated into the sequencing vector pUC-18. The magainin coding region was then ligated into a chimeric gene including promoter, leader sequence and export peptide, and terminator which was derived from pMOG18 [31]. The resulting chimeric gene contains a duplicated CaMV 35S promoter [32] which directs high level constitutive gene expression in plants; an untranslated leader sequence from the coat protein gene of alfalfa mosaic virus (AMV), which has been shown to enhance translation [33]; and the signal sequence from tobacco pathogenesis related (PRS) gene [34], which directs export of proteins into the intercellular space after translation. Finally,

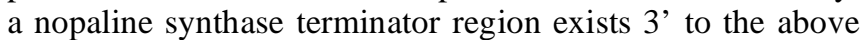
sequences for termination of transcription (Fig. 1). After confirmation of sequence integrity, the chimeric magaininD gene (Fig. 1) was then ligated into the binary vector pBINPLUS [35]. The resulting binary vector was transferred to Agrobacterium as described by Höfgen and Willmitzer [36].

\section{Tissue Culture and Transformation}

Virus-free potato cultivar Iwa was transformed with $A$. tumefaciens disarmed strain EHA105 [37] harbouring the binary vector pBINMgD according to Barrell et al. [38]. After cell colony initiation and shoot regeneration, one shoot was picked from each individual regenerating colony. Each shoot was multiplied in a separate container on potato multiplication medium (containing the salts and vitamins of $\mathrm{Mu}$ rashige and Skoog [39] plus $40 \mathrm{mg} / \mathrm{L}$ ascorbic acid, 500 $\mathrm{mg} / \mathrm{L}$ casein hydrolysate, $30 \mathrm{~g} / \mathrm{L}$ sucrose, $6 \mathrm{~g} / \mathrm{L}$ agar, and 100 $\mathrm{mg} / \mathrm{L}$ Timentin). Shoots were subsequently subcultured onto the same medium with 50-100 mg/L kanamycin. Plants were maintained on potato multiplication medium containing 100 $\mathrm{mg} / \mathrm{L}$ Timentin.

\section{Southern Blot Analysis}

Southern blot analysis was carried out essentially according to Sambrook et al. [40]. DNA was digested with EcoRI, which cuts once within the binary vector. Membranes were probed with the $1.4 \mathrm{~Kb}$ EcoRI-HinDIII fragment of pBINMgD that contained the chimeric magainin gene.

\section{RT-PCR Analysis}

PCR primers were designed to bind to the 5 , region of the PRS sequence, and to the 5' region of the NOS terminator. Primer sequences were as follows: MgRNA F 5' atgaacttcctcaagagcttc 3'; MgRNA R 5' gccaaatgtttgaacgatcgg

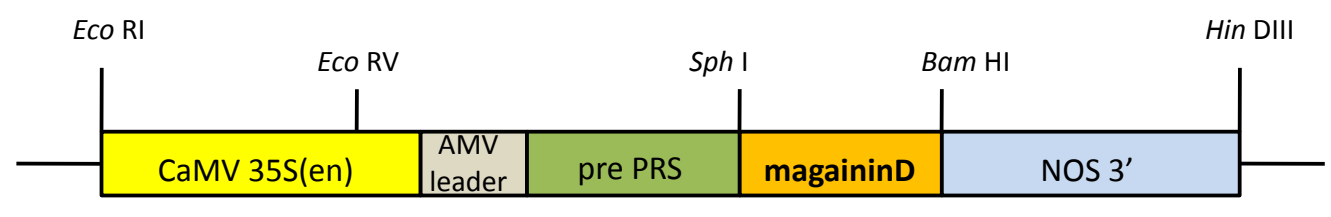

\begin{tabular}{|l|l|l|l|}
\hline $0.85 \mathrm{~kb}$ & $0.1 \mathrm{~kb}$ & $0.07 \mathrm{~kb}$ & $0.3 \mathrm{~kb}$ \\
\hline
\end{tabular}

Fig. (1). Map of the chimeric magaininD gene ligated into the binary vector pBINPLUS for plant transformation. 
3'. RT-PCR reactions were performed using total RNA as template. RNA was extracted from $100 \mathrm{mg}$ of in vitro plant leaves from each line, using Trizol (Invitrogen, Carlsbad, CA, USA) according to the manufacturer's instructions. After precipitation of the resulting RNA, it was re-dissolved in $100 \mu \mathrm{L}$ of DEPC treated water. Solubilised RNA was treated with RNase-free DNase (Roche Diagnostics, Mannheim, Germany) for $30 \mathrm{~min}$ at $25{ }^{\circ} \mathrm{C}$ in order to destroy any contaminating DNA. The samples were heated to $70^{\circ} \mathrm{C}$ for 5 min, to denature the RNA and destroy the DNase. Reverse transcription was achieved by placing primers, SuperScript II (Invitrogen) and associated $10 \mathrm{X}$ buffers including DTT into a single reaction tube containing a Ready-To-Go PCR bead (Amersham Pharmacia Biotech, Piscataway, NJ USA), with $2 \mu \mathrm{L}$ RNA and DEPC treated water. The PCR program consisted of a single incubation at $42^{\circ} \mathrm{C}$ for $40 \mathrm{~min}$ for reverse transcription, followed by 38 cycles of: $93^{\circ} \mathrm{C}(30 \mathrm{sec}) ; 53^{\circ} \mathrm{C}$ (30 sec); $72^{\circ} \mathrm{C}(30 \mathrm{sec})$.

\section{Western Analysis}

Protein extraction: Samples of in vitro potato leaves (100 $\mathrm{mg}$ ) were transferred to a $1.5 \mathrm{~mL}$ microfuge tube before being ground in buffer comprising $0.1 \mathrm{~mL}$ of $0.2 \mathrm{M} \mathrm{NaOAc} \mathrm{pH}$ 4.0, 0.2\% SDS, $10 \mathrm{mM}$ EDTA, $1 \mathrm{mM}$ PMSF, plus one mini protease inhibitor tablet (Roche Diagnostics) per $10 \mathrm{~mL}$. The slurry was centrifuged at $12000 \mathrm{X} g$ for $5 \mathrm{~min}$ at $4^{\circ} \mathrm{C}$, and $120 \mu \mathrm{L}$ of the supernatant transferred to a fresh tube. To maximise the amount of protein able to be loaded on the gel, and therefore to maximise the likelihood of detecting the transgenic peptide, the tube was placed in a rotary vacuum evaporator until the volume had approximately halved. Control samples included non-transformed potato cultivar Iwa; and Iwa spiked with (Ala 8, 13, 18)-magainin II amide (Sigma, MO, USA), a peptide one amino acid different to the predicted translated magaininD amino acid sequence.

Sample preparation prior to electrophoresis: Prior to denaturation in a heat block at $95^{\circ} \mathrm{C}$ for $5 \mathrm{~min}, 0.167$ volumes of 6 X SDS loading buffer $(0.35 \mathrm{M}$ Tris $\mathrm{pH} 6.8 ; 10.28 \%$ SDS; $36 \%$ glycerol; $5 \% \beta$-mercaptoethanol, $0.012 \%$ bromophenol blue) was added to each sample. The samples were centrifuged at $12000 \mathrm{Xg}$ for $10 \mathrm{~min}$. The $\mathrm{pH}$ of the samples was adjusted from 4.0 back toward neutrality by the addition of Tris crystals to each sample until the bromophenol blue in the loading buffer had regained a blue colour. Aliquots of ten or $20 \mu \mathrm{L}$ of the final supernatant were electrophoresed on duplicate SDS-PAGE 10-20\% gradient tris-tricine 'Ready Gels' (Bio-Rad). Running buffer comprised $100 \mathrm{mM}$ Tris, $100 \mathrm{mM}$ tricine, 0.1\% SDS. Samples were electrophoresed at 70 V. One gel was stained with Coomassie Brilliant Blue G250 , and protein in the other gel transferred to PVDF.

Western blot procedure: After electrophoresis, gels to be transferred to PVDF were soaked in transfer buffer comprising $25 \mathrm{mM}$ Tris, $192 \mathrm{mM}$ glycine and 20\% methanol, for a maximum of $10 \mathrm{~min}$ prior to transfer. Protein was transferred to Sequi-Blot PVDF (Bio-Rad) pre-wet in $100 \%$ methanol, using a Mini Trans-Blot Transfer Cell (Bio-Rad) in transfer buffer pre-cooled to $4^{\circ} \mathrm{C}$. $100 \mathrm{~V}$ was applied for $50 \mathrm{~min}$.

After transfer, membranes were blocked in $1 \mathrm{X}$ Trisbuffered saline (TBS) containing 5\% non-fat dried milk powder (NFDMP) for $1 \mathrm{~h}$ with gentle shaking at room temperature or overnight at $4^{\circ} \mathrm{C}$. All subsequent steps were per- formed at room temperature. Membranes were washed for 3 $\mathrm{X} 10$ min in TTBS (TBS containing $0.1 \%$ Tween 20) before exposure to the primary anti-magaininD antibody [41] in a solution of TTBS containing 1\% NFDMP, for 1-1.5 h with gentle shaking. Excess primary antibody was washed from the blot with three washes, each of $10 \mathrm{~min}$ in TTBS. The biotinylated secondary antibody was applied in a solution of TTBS also containing biotinylated alkaline phosphatase and streptavidin (Bio-Rad) for $1 \mathrm{~h}$ with gentle shaking. Excess secondary antibody/streptavidin/alkaline phosphatase solution was removed with three further washes in TTBS of 10 min each. Colour was developed using 5-Bromo-4-chloro-3indolyl phosphate/Nitro blue tetrazolium (BCIP/NBT tablets, Sigma) according to the manufacturer's instructions.

\section{Field Trial Design}

Control and transgenic tubers were produced in the field from virus-free in vitro plantlets. Each transgenic line was clonally multiplied via micropropagation, transferred to a containment greenhouse and hardened-off using standard procedures [42]. The resulting plants were used for establishing field trials over three consecutive southern hemisphere summers $(2000 / 01,2001 / 02$ and 2002/03). Rows of the potato plants were spaced $75 \mathrm{~cm}$ apart, with $30 \mathrm{~cm}$ between plants within rows. Ten plants of each line were transplanted as a single plot within a row, with a $1 \mathrm{~m}$ gap between plots. Plots of these transgenic lines were interspersed with plots of the appropriate non-transgenic controls. Control lines included: A206, a somatic hybrid between Solanum brevidens and potato, which has high levels of resistance to soft rot disease; the potato genotype CR4\#2, highly susceptible to soft rot (and also the potato genotype used to create the somatic hybrid line A206) [43]; and lines SI20d and DG1a for the 2000/01 and 2002/03 field seasons respectively, which were cultivar Iwa transgenic for a cry9Aa2 gene [44] and used as vector controls. The experimental plots were completely surrounded by plots from trials of other transgenic potatoes or three buffer rows of non-transgenic potato (breeding line 2390) to prevent "edge effects" during the trial. Weeding was done by hand and potato plants were subjected to overhead irrigation as required during crop establishment. Rows were mounded once, 4 to 6 weeks after planting.

\section{Soft Rot Assay}

After harvest and storage for 6 to 12 weeks at $10^{\circ} \mathrm{C}$, tuber bioassays were performed following Wright et al. [45]. Erwinia carotovora ssp. atroseptica (ICMP 8975 [46]) was grown overnight at $28^{\circ} \mathrm{C}$ in $50 \mathrm{~mL}$ of $\mathrm{LB}$ medium. The culture was centrifuged at $7000 \mathrm{X} \mathrm{g}$. The LB medium was discarded and the cells resuspended in $100 \mathrm{~mL}$ distilled water. For each transgenic potato line, ten tubers of even size (approximately $100 \mathrm{~g}$ ), were inoculated with the diluted Erwinia culture as follows: a cork borer was used to make a hole $3 \mathrm{~mm}$ diameter by $10 \mathrm{~mm}$ deep, halfway between the rose and heel ends of the tuber. An aliquot of $50 \mu \mathrm{L}$ of the diluted Erwinia culture was dispensed into the hole by pipette, and the plug of tuber tissue replaced. The hole was sealed with petroleum jelly. The tubers were placed in plastic containers. Tubers were incubated at $22^{\circ} \mathrm{C}$ for 1 week. After incubation, each tuber was weighed, the rotted tissue removed by washing, and the tuber re-weighed after blotting 
dry with a paper towel. Weights $(\mathrm{g})$ of tubers were recorded before and after rotted tissue was removed. Susceptibility to soft rot was assessed by the amount of tissue lost after rotted tissue was removed.

\section{Statistical Analysis}

The data for each soft rot bioassay were analysed separately. The changes in weight of each tuber were analysed with analysis of variance. The data were transformed to a log scale before analysis to make the variance more homogeneous across lines. Analysis used GenStat [47].

\section{RESULTS}

\section{Plant Transformation and Southern Analysis}

Transformation of potato leaves with $\mathrm{pBINMgD}$ resulted in 26 independently transformed lines, as confirmed by Southern analysis. Southern analysis showed transgene copy number in the lines number ranged from one to seven (Table 1).

Table 1. Summary of Molecular Analyses. Southern Analysis, RT-PCR and Western Analysis of the 26 Independently Derived MagaininD-Transgenic Potato Lines. RT-PCR and MagaininD Peptide Expression is Shown as: ' + ' Indicating Expression, '_' Indicating no Expression, '?' Indicating Possible Expression, but Band was Very Faint

\begin{tabular}{|c|c|c|c|}
\hline Plant Line & $\begin{array}{c}\text { Southern } \\
\text { Copy Number }\end{array}$ & RT-PCR & Peptide Expression \\
\hline \hline MgD1 & 1 & + & + \\
\hline MgD2 & 1 & + & $?$ \\
\hline MgD3 & 6 & + & $?$ \\
\hline MgD4 & 1 & + & $?$ \\
\hline MgD5 & 1 & + & + \\
\hline MgD6 & 2 & + & - \\
\hline MgD8 & 6 & + & - \\
\hline MgD9 & 6 & + & + \\
\hline MgD10 & 4 & + & - \\
\hline MgD15 & 2 & + & - \\
\hline MgD16 & 7 & + & - \\
\hline MgD17 & 1 & + & - \\
\hline MgD18 & 5 & + & + \\
\hline MgD19 & 5 & + & - \\
\hline MgD22 & 2 & + & - \\
\hline MgD24 & 4 & + & - \\
\hline MgD25 & 2 & + & - \\
\hline MgD27 & 1 & - & - \\
\hline MgD28 & 1 & + & - \\
\hline MgD29 & 1 & + & - \\
\hline MgD30 & 1 & + & - \\
\hline MgD32 & 1 & + & - \\
\hline MgD33 & 5 & + & - \\
\hline MgD34 & 2 & + & - \\
\hline MgD39 & 5 & + & - \\
\hline MgD50 & 2 & + & - \\
\hline
\end{tabular}

\section{RT-PCR Analysis}

A representative example of products obtained from RTPCR analysis of selected potato lines is shown in Fig. (2). A high frequency of expression of RNA was observed, with 25 of the 26 magaininD plant lines expressing the transgene at the RNA level (Table 1).

\section{Western Analysis}

An example of western analysis including six transgenic lines (MgD1, MgD2, MgD3, MgD4, MgD5 and MgD9) is presented in Fig. (3). A faint reaction with the antibodies can be seen in the Iwa control (lane 2), but in the next lane (lane 3) which comprised the same Iwa control spiked with (Ala 8, 13, 18)-magainin II amide, a reaction can be seen at a higher molecular weight. Transgenic lines $\mathrm{MgD} 1, \mathrm{MgD}$, and MgD9 (lanes 4, 8, and 9, Fig. 3) showed intense bands on the western blot indicating that they express the magainin peptide. Transgenic lines MgD2, MgD3 and MgD4 (lanes 5, 6, and 7, Fig. 3) also showed a reaction to the antibodies of the correct size, although the reaction was less intense, especially for the latter two lines. Although the band was no stronger than the smaller peptide in the Iwa control lane, it was of higher molecular weight. Line MgD9 (Lane 9) showed a strong reaction that appeared higher in molecular weight than the other lines. The corresponding lane in Coomassie-stained extracts showed a high amount of protein in the same location, which could be transgene-derived peptide. A summary of the western analysis is given in Table $\mathbf{1}$.

\section{Soft Rot Assays on Field Grown Tubers}

All transgenic lines exhibiting magainin production from western analysis were established in field trials. Line MgD18 failed to produce tubers of sufficient size and quality and was therefore not included in the soft rot assays. The changes in tuber weight (loss of tissue) resulting from soft rot was evaluated using analysis of variance. In all four bioassays there were significant differences between the lines ( $p<0.001)$. Control lines A206 and CR4\#2 behaved as expected. Line A206 had the least amount of rotted tissue and was the most resistant of all the lines tested, whereas CR4\#2 was highly susceptible, with all tubers inoculated having lost large amounts of tissue due to Erwinia infection. The vector controls, transformed lines with a cry9Aa2 gene rather than the magainin gene, were not significantly different from the non-transgenic Iwa controls. The response of tubers from all the control lines indicates that the bioassay was successful in detecting resistance to soft rot bacteria (Table 2).

In all four bioassays, MgD1 had a significantly $(\mathrm{p}<0.05)$ reduced loss of tissue due to soft rot than the non-transgenic Iwa control. Similarly, the weight changes for MgD5 and MgD39 were also significantly lower $(p<0.05)$ than Iwa for the latter three bioassays. Although the weight changes for $\mathrm{MgD} 5$ and MgD39 were similar in all four soft rot bioassays, they were not statistically lower than Iwa in the first assay. This is probably a consequence of the mean variability (represented by the LSR) being slightly greater in the first bioassay, and the mean loss of tissue due to soft rot in the nontransgenic Iwa being almost half that found in the latter three assays. The loss of tissue due to soft rot was not significantly different from the non-transgenic Iwa control for all the other transgenic lines in all four soft rot bioassays (MgD2, 


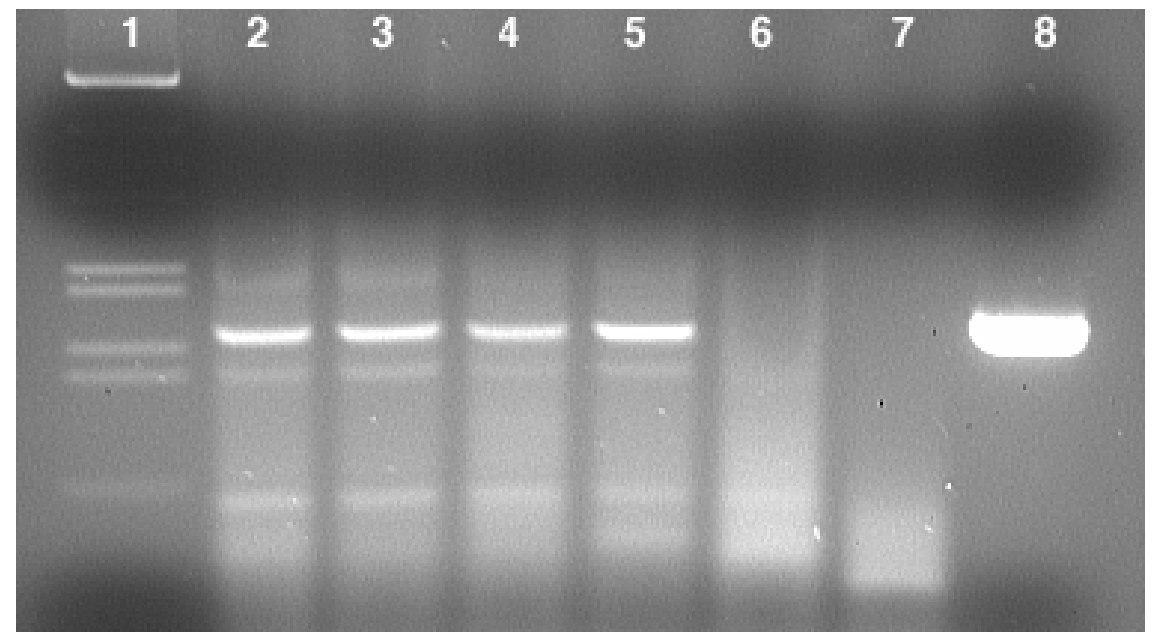

Fig. (2). RT-PCR of selected potato plants transgenic for the magainin construct. PCR primers were designed to bind to the 5' region of the PRS signal peptide of the chimeric gene, and just past the 3' end of the magainin gene on the NOS terminator. Expected size product was 152 bp. PCR products were electrophoresed on a 2\% NuSieve (FMC) agarose gel. Lane 1: $1 \mathrm{~Kb}$ marker; lanes 2-5: magaininD-transgenic lines; lane 6: non-transgenic Iwa negative control; lane 7: no reverse transcriptase negative control; lane 8: PCR of plasmid pBINMgD positive control. The gel shows that the bands amplified in RT-PCR analysis of the transgenic plants were of the expected size, and the same size as amplification product of the plasmid containing the transgene used to transform the plants.

$\mathrm{MgD} 3, \mathrm{MgD} 4, \mathrm{MgD}$ ). Transgenic lines $\mathrm{MgD} 2$ was least consistent between the years, having quite a low weight change in the first assay, but high in the remaining assays.

\section{DISCUSSION}

A major goal for plant biotechnology is genetic engineering of disease and insect resistance in crops [48, 49]. The overall goal of this project was to determine whether genetically engineered potato plants harbouring a synthetic antimicrobial magainin gene would have improved resistance to bacterial soft rot disease caused by E. carotovora. Magainin peptides have significant antibacterial activity, and inhibit the in vitro growth of $E$. carotovora, the cause of soft rot disease in potato [19]. A synthetic gene based on magainin II [15] was therefore engineered. The modifications made to the magainin II peptide [15] included a single point mutation altering the seventh His residue substituted to Arg, which was reported to increase the peptide's stability against protease cleavage [28]. Three Ala substitutions were also included at the eighth, 13th and 18th positions, which when translated increase the helical propensity of the peptide, resulting in increased antimicrobial activity [29].

Transformation of potato via Agrobacterium-mediated techniques has become routine $[38,50-52]$, and 26 independently transformed magaininD lines were easily generated in this study. Southern analysis was performed on all transgenic plants, and copy number of each line was obtained. RT-PCR determined which lines expressed the transgene at the RNA level. Overall, a high frequency of expression of RNA was observed, with all except one of the lines transcribing the transgene into RNA. The observation that a high frequency of potato lines transgenic for magainin genes driven by the CaMV $35 \mathrm{~S}$ promoter, were expressing the transgene at the RNA level matches other reports of transgenic RNA expression in potato. For example, Liew [30] reported that northern analysis of potato plants transgenic for atrial natriuretic factor driven by the CaMV $35 \mathrm{~S}$ promoter had a high frequency of lines exhibiting RNA expression.

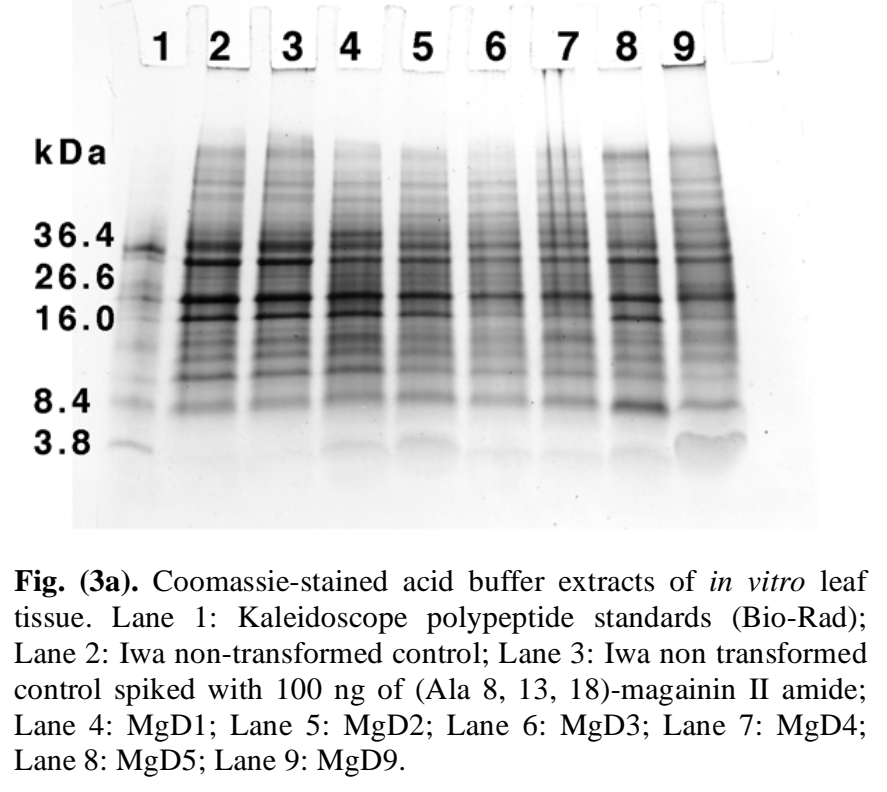

$\mathrm{kDa}$

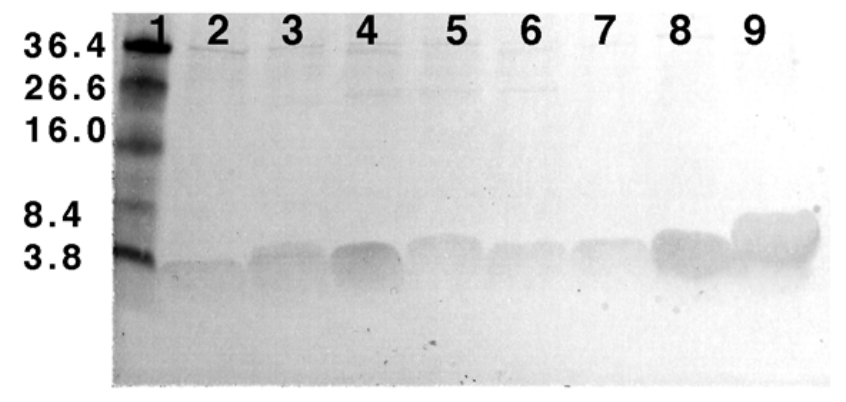

Fig. (3b). Western blot of the duplicate gel in (a) above. Extracts in Lanes 4,8 , and 9 show strong reaction to anti-magainin antibodies showing the magainin peptide is most likely being translated in the respective lines. 
Similarly, Gatehouse et al. [53] reported via dot-blot analysis that the majority of potato transformants transgenic for snowdrop lectin, bean chitinase, or wheat $\alpha$-amylase genes, all driven by the CaMV $35 \mathrm{~S}$ promoter, had significant transgene RNA levels.

Table 2. Soft Rot Assays. Four Independent Soft Rot Assays were Performed on Tuber Produced on Field Grown Plants Over Three Consecutive Years: Assay 1 (2000/01 Season, 6 Weeks Tuber Storage); Assay 2 (2001/02 Season, 10 Weeks Tuber Storage); Assay 3 (2002/03 Season, 6 Weeks Tuber Storage) Assay 4 (2002/03 Season, 12 Weeks Tuber Storage)

\begin{tabular}{|c|c|c|c|c|}
\hline Line & Assay 1 & Assay 2 & Assay 3 & Assay 4 \\
\hline \hline Iwa & 2.62 & 4.62 & 4.84 & 4.67 \\
\hline MgD1 & 1.46 & 2.26 & 2.06 & 2.26 \\
\hline MgD2 & 1.96 & 5.13 & 4.58 & 3.99 \\
\hline MgD3 & 3.77 & 4.41 & 5.68 & 5.87 \\
\hline MgD4 & 4.11 & 4.49 & 4.99 & 5.45 \\
\hline MgD5 & 2.15 & 2.20 & 3.03 & 2.92 \\
\hline MgD9 & 3.73 & 4.69 & 4.47 & 3.94 \\
\hline MgD39 & 2.05 & 2.13 & 1.95 & 2.03 \\
\hline Vector control & 3.21 & - & 6.20 & 4.92 \\
\hline Cr4\#2 & 9.81 & 6.80 & 9.99 & 9.49 \\
\hline A206 & 0.32 & 1.26 & 1.05 & 1.35 \\
\hline LSR 5\% & 1.737 & 1.224 & 1.262 & 1.328 \\
\hline
\end{tabular}

LSR: Least significant ratio (larger mean/smaller mean) for two means to be significantly different at the 5\% level. Degrees of freedom were 99 for assays 1, 3, and 4, 90 for assay 2 . The figures are back-transformed values of the mean of the logarithmtransformed data $(\mathrm{n}=10)$.

Transgenic plants with enhanced resistance to microbial diseases have been reported in the past 10 years. However, many of these reports do not have information on the detection of the transgene-derived peptide [e.g. 11, 13, 14, 26, 27, 54]. In the absence of protein analysis, it is difficult to attribute the resistance specifically to the expression of the transgene-derived peptide.

The magaininD peptide sequence is four amino acids different from the original magainin II peptide sequence. The antibodies used in our western analyses were raised specifically against the exact magaininD sequence [41] and not magainin II. We were able to assay expression of the magaininD transgene at the protein level with the use of these specific antibodies. Although our western analyses were performed on protein extracts from leaf tissue, others have previously shown that the $35 \mathrm{~S}$ promoter coupled to the $\beta$ glucuronidase gene resulted in GUS expression in all parts of potato plants including leaves and tubers [55]. We also used the 35S promoter in our construct. Therefore if transgenederived peptide is detected in leaf tissue, it should also be present in other parts of the potato plant.

Western analysis showed that magaininD peptide was detected in five lines (MgD1, MgD5, MgD9, MgD18, and $\mathrm{MgD} 39$ ), and weakly detected in three additional lines (MgD2, MgD3 and MgD4). The positive result in detecting transgene-derived protein indicated that the construction of synthetic magainin coding regions from primers, using potato codon usage (combined with signal sequence, 5' and 3' non-translated regions identical to those used by Sijmons $e t$ al., 1990) was a successful approach for expressing magainin peptides in transgenic plants.

Transgenic plants must be container-grown under New Zealand guidelines for containment greenhouses. Potato plants grown in pots or bags usually produce tubers with a wide variance within the same line in response to soft rot assays (authors' unpublished results). Additionally, the effects of somaclonal variation, which may result in "off-type" phenotypes, may not always be apparent in plants grown in the relatively stable containment greenhouse conditions $[42$, 56]. Therefore, it was important to assess tubers grown in field conditions in the soft rot bioassays.

High levels of resistance to soft rot-inducing Erwinia species have been found in Solanum brevidens, a non-tuber forming wild species that cannot be sexually hybridised to cultivated potato. Protoplast fusions between the diploid $S$. brevidens and tetraploid potato result in a hexaploid somatic hybrid that also shows high levels of resistance to Erwinia bacteria [43]. The degree of methyl esterification of pectin is known to be the cause of the resistance in these somatic hybrids [57]. While the hybrid may provide a suitable method for introgression of resistance to tetraploid potatoes via a long-term breeding programme, these somatic hybrids usually result in very small unusual shaped tubers, and resistance associated with cell wall pectins introgressed into potato may have negative effects on tuber quality. However, this somatic hybrid provided a valuable positive control in the soft rot bioassays.

Three transgenic magaininD lines (MgD1, MgD5, MgD39) gave statistically significant less rot than control Iwa tubers in soft rot tuber bioassays. These three lines also tested positive in western analysis for production of magainin peptides (Fig. 3). Therefore the improved resistance observed is most likely due to the production of transgenederived magainin peptides acting against $E$. carotovora ssp. atroseptica.

The resistance observed in the magaininD-transgenic lines was not as great as that observed for the somatic hybrid line A206. The resistance to bacterial infection in somatic hybrids between potato and S. brevidens (e.g. line A206) has been attributed to a higher degree of esterification of pectin [57]. Therefore the enzymes produced by Erwinia species may be ineffective in breaking down the cell walls with a higher degree of esterification of pectin in these somatic hybrid lines [57]. This form of resistance is through a different mechanism than that attempted in this work, of introducing synthetic antimicrobial genes that when expressed produce antimicrobial peptides.

The soft rot bioassay as described in this paper was a very severe test. It is unlikely that tubers grown under normal field conditions would encounter the billions of Erwinia bacteria at one time as in the assay used in this experiment. The expression of the transgene-derived peptide may be successful in preventing Erwinia bacteria from multiplying to the threshold level required to initiate rot. In aerobic conditions this is $10^{6}-10^{7}$ cells [58]. Since a soft rot resistance 
phenotype was observed under these highly stringent conditions, the expression of transgene-derived magainin peptides may be effective in preventing Erwinia from initiating soft rot in tubers under normal field or storage conditions.

Several reasons may account for why other transgenic lines that expressed the magainin peptide showed no significant improvement in resistance to soft rot disease caused by E. carotovora. The effect of the position of the transgene within the potato genome may result in varied levels of expression of the peptide. Transgene expression can be highly variable between different plant lines transformed with the same transgene [e.g. 59]. The transgenic lines MgD1, MgD5 and MgD39 had the highest level of expression of transgenederived peptide as judged by the intensity of bands upon western analysis (Table 1, Fig. 3). One other transgenic line (MgD9) exhibited a band of similar intensity, but at a larger than expected size (Fig. 3). This may have represented the peptide signal sequence not cleaving and a failure to export the magainin into the intercellular space. All the other transgenic lines, without improved resistance to soft rot disease, may have had insufficient levels of transgene-derived peptide to effect resistance. The use of alternative promoters may provide higher levels of expression than those seen with the CaMV 35S promoter used to drive the magainin genes described in this work.

The observation of resistance to soft rot in lines MgD1, MgD5 and MgD39 was similar to the results observed by Allefs et al. [9], who reported that expression of the antimicrobial peptide tachyplesin in potato provided slightly improved resistance to soft rot. Additionally, enhanced resistance to bacterial infection by Erwinia in potato plants transgenic for an antimicrobial cecropin B gene was also reported by Arce $e t a l$. [11].

In summary, the results presented show that the strategy for the design and construction of a synthetic antimicrobial magainin gene was effective in producing plants with improved antimicrobial activity and disease resistance. This represents a novel form of soft rot resistance in potato which may be useful for genetic manipulation in a wide range of plant species.

\section{ACKNOWLEDGEMENTS}

We thank J. Reader and M. Davidson for help with field trials; V. Meiyalaghan for help with the 2002/03 soft rot bioassays; R. Butler for help with statistical analysis; and O.W. Liew for advice on western analysis.

\section{REFERENCES}

[1] Düring K. Genetic engineering for resistance to bacteria in transgenic plants by introduction of foreign genes. Mol Breed 1996; 2: 297-305.

[2] Hightower R, Baden C, Penzes E, Dunsmuir P. The expression of cecropin peptide in transgenic tobacco does not confer resistance to Pseudomonas syringae pv tabaci. Plant Cell Rep 1994; 13: 295-99.

[3] Shah DM. Genetic engineering for fungal and bacterial diseases. Curr Opin Biotechnol 1997; 8: 208-14.

[4] Mourgues F, Brisset M-N, Chevreau E. Strategies to improve plant resistance to bacterial diseases through genetic engineering. Trends Biotechnol 1998; 16: 203-10.

[5] Pérombelon MCM, Kelman A. Ecology of the soft rot Erwinias. Ann Rev Phytopathol 1980; 18: 361-87.

[6] Pérombelon MCM. Potato blackleg: epidemiology, host-pathogen interaction and control. Netherlands J Plant Pathol 1992; 98: 13546.
[7] Wegener C, Jansen G. The susceptibility of tissue cell walls to Erwinia enzymes differs among the potato cultivars. Potato Res 1996; 39: 515-22

[8] Nielsen LW. The susceptibility of seven potato varieties to bruising and bacterial soft rot. Phytopathology 1954; 44: 30-5.

[9] Allefs SJHM, De Jong ER, Florack DEA, Hoogendoorn C. Erwinia soft rot resistance of potato cultivars expressing antimicrobial peptide tachyplesin I. Mol Breed 1996; 2: 97-105.

[10] Huang Y, Nordeen RO, Di M, Owens LD, McBeath JH. Expression of an engineered cecropin gene cassette in transgenic tobacco plants confers disease resistance to Pseudomonas syringae pv. Tabaci. Phytopathology 1997; 87: 494-9.

[11] Arce P, Moreno M, Gutierrez M, et al. Enhanced resistance to bacterial infection by Erwinia carotovora subsp. atroceptica in transgenic potato plants expressing the attacin or the cecropin SB37 genes. Am J Potato Res 1999; 76: 169-77.

[12] Osusky M, Zhou G, Osuska L, Hancock RE, Kay WW, Misra S. Transgenic plants expressing cationic peptide chimeras exhibit broad-spectrum resistance to phytopathogens. Nat Biotechnol 2000; 18: 1162-6.

[13] Li Q, Lawrence CB, Xing H-Y, et al. Enhanced disease resistance conferred by expression of an antimicrobial magainin analog in transgenic potato. Planta 2001; 212: 635-9.

[14] DeGray G, Rajasekaran K, Smith F, Sanford J, Daniell H. Expression of an antimicrobial peptide via the chloroplast genome to control phytopathogenic bacteria and fungi. Plant Physiol 2001; 127: 852-62.

[15] Zasloff M. Magainins, a class of antimicrobial peptides from Xenopus skin: isolation, characterization of two active forms, and partial cDNA sequence of a precursor. Proc Natl Acad Sci USA 1987; 84: 5449-53.

[16] Hancock REW. Peptide antibiotics. Lancet 1997; 349: 418-22.

[17] Powell WA, Catranis CM, Maynard CA. Synthetic antimicrobial peptide design. Mol Plant Microbe Interact 1995; 8: 792-4.

[18] Kristyanne ES, Kim KS, Stewart JM. Magainin 2 effects on the ultrastructure of five plant pathogens. Mycologia 1997; 89: 353-60.

[19] Wilson CR, Conner AJ. Activity of antimicrobial peptides against the causal agents of common scab, blackleg and tuber soft rot diseases of potato. N Z Nat Sci 1995; 22: 43-50.

[20] Alan AR, Earle ED. Sensitivity of bacteria and fungal plant pathogens to the lytic peptides, MSI-99, magainin II and cecropin B. Mol Plant Microbe Interact 2002; 15: 701-8.

[21] Bechinger B. Structure and functions of channel-forming peptides: magainins, cecropins, melittin and alamethicin. J Membr Biol 1997; 156: 197-211.

[22] Bechinger B. The structure, dynamics and orientation of antimicrobial peptides in membranes by multidimensional solid-state NMR spectroscopy. Biochim Biophys Acta Biomembr 1999; 1462: 15783.

[23] Sharma A, Khoury-Christianson AM, White SP, et al. Highefficiency synthesis of human $\alpha$-endorphin and magainin in erythrocytes of transgenic mice: a production system for therapeutic peptides. Biochemistry 1994; 91: 9337-41.

[24] Everett NP. Design of Antifungal Peptides for Agricultural Applications, In: Hedin E, Menn J, Hollingworld R, Eds. Natural and Engineered Pest Management Agents. American Chemical Society: Washington 1994; pp. 278-91.

[25] Düring K, Porsch P, Fladung M, Lörz H. Transgenic potato plants resistant to the phytopathogenic bacterium Erwinia carotovora. Plant J 1993; 3: 587-98.

[26] Alan AR, Blowers A, Earle ED. Expression of a magainin-type antimicrobial peptide gene (MSI-99) in tomato enhances resistance to bacterial speck disease. Plant Cell Rep 2004; 22: 388-96.

[27] Chakrabarti A, Ganapathi TR, Mukherjee PK, Bapat VA. MSI-99, a magainin analogue, imparts enhanced disease resistance in transgenic tobacco and banana. Planta 2003; 216: 587-96.

[28] Mapelli C, Dugas de Robertis C, Stahl G, et al,. Antimicrobial peptides and their use against plant pathogens. European Patent Office EP 0497366A2. 1992.

[29] Chen H-C, Brown JH, Morell JL, Huang CM. Synthetic magainin analogues with improved antimicrobial activity. FEBS Lett 1988; 236: 462-6.

[30] Liew OW. Expression of atrial natriuretic factor in transgenic potatoes. Ph.D. Thesis, Lincoln University, Lincoln, New Zealand 1994. 
[31] Sijmons PC, Dekker BMM, Schrammeijer B, Verwoerd TC, van den Elzen PJM, Hoekema A. Production of correctly processed human serum albumin in transgenic plants. Biotechnology 1990; 8: 217-21.

[32] Kay R, Chan A, Daly M, McPherson J. Duplication of CaMV 35S promoter sequences creates a strong enhancer for plant genes. Science 1987; 236: 1299-302.

[33] Jobling SA, Gehrke L. Enhanced translation of chimaeric messenger RNAs containing a plant viral untranslated leader sequence. Nature 1987; 325: 622-5.

[34] Cornelissen BJC, Hooft van Huijsduijnen RAM, Bol JF. A tobacco mosaic virus-induced tobacco protein is homologous to the sweettasting protein thaumatin. Nature 1986; 321: 531-2.

[35] van Engelen FA, Molthoff JW, Conner AJ, Nap J-P, Pereira A, Stiekema WJ. pBINPLUS: an improved plant transformation vector based on pBIN19. Transgenic Res 1995; 4: 288-90.

[36] Höfgen R, Willmitzer L. Storage of competent cells for Agrobacterium transformation. Nucl Acids Res 1988; 16: 9877.

[37] Hood EE, Gelvin SB, Melchers LS, Hoekema A. New Agrobacterium helper plasmids for gene transfer to plants. Transgenic Res 1993; 2: 208-18.

[38] Barrell PJ, Yongjin S, Cooper PA, Conner AJ. Alternative selectable markers for potato transformation using minimal T-DNA vectors. Plant Cell Tissue Organ Cult 2002; 70: 61-8.

[39] Murashige T, Skoog F. A revised medium for rapid growth and bioassays with tobacco tissue cultures. Physiol Plant 1962; 15: 47397.

[40] Sambrook J, Fritsch EF, Maniatis T. Molecular Cloning: A laboratory manual. $2^{\text {nd }}$ edn. Cold Spring Harbor Laboratory Press: New York 1989.

[41] Barrell PJ, Liew OW, Conner AJ. Expressing an antibacterial protein in bacteria for raising antibodies. Protein Expr Purif 2004; 33: 153-9.

[42] Conner AJ, Williams MK, Abernethy DJ, Fletcher PJ, Genet RA. Field performance of transgenic potatoes. NZ J Crop Hort Sci 1994; 22: 361-71.

[43] Austin S, Lojkowska E, Ehlenfeldt MK, Kelman A, Helgeson JP. Fertile interspecific somatic hybrids of Solanum: a novel source of resistance to Erwinia soft rot. Phytopathology 1988; 78: 1216-20.

[44] Gleave AP, Mitra DS, Markwick NP, Morris BAM, Beuning LL. Enhanced expression of the Bacillus thuringiensis cry9Aa2 gene in transgenic plants by nucleotide sequence modification confers resistance to potato tuber moth. Mol Breed 1998; 4: 459-72.

[45] Wright PJ, Crowhurst RN, Anderson JAD, Dale JR. Evaluation of potato cultivars and breeding lines for susceptibility to tuber soft rot induced by Erwinia carotovora subsp. atroceptica. NZ J Crop Hort Sci 1991; 19: 187-90.

[46] Young JM, Fletcher MJ. International Collection of Microorganisms from Plants. $3^{\text {rd }}$ edn. Landcare Research: Auckland 1997.

[47] Genstat Committee. Genstat 5 release 4.2. Reference Manual, Parts 1-3. Numerical Algorithms Group: Oxford 2000.

[48] Rao AG. Antimicrobial peptides. Mol Plant Microbe Interact 1995; 8: 6-13.

[49] Ortiz R. Critical role of plant biotechnology for the genetic improvement of food crops: perspectives for the next millennium. Electron J Biotechnol 1998; 1: 1-8.

[50] An G, Watson BD, Chiang CC. Transformation of tobacco, tomato, potato and Arabidopsis thaliana using a binary Ti vector system. Plant Physiol 1986; 81: 301-5.

[51] Conner AJ, Williams MK, Gardner RC, Deroles SC, Shaw ML, Lancaster JE. Agrobacterium-mediated transformation of New Zealand potato cultivars. NZ J Crop Hort Sci 1991; 19: 1-8.

[52] Rockhold DR, MacCree MM, Belknap WR. Transgenic potato (Solanum tuberosum L.) In: Bajaj YPS, Ed. Transgenic Crops II. Springer: Berlin 1999; pp. 305-24.

[53] Gatehouse AMR, Davison GM, Newell CA, Merryweather A, Hamilton WDO, Burgess EPJ. Transgenic potato plants with enhanced resistance to the tomato moth, Lacanobia oleracea: growth room trials. Mol Breed 1997; 3: 49-63.

[54] Liu Q, Ingersoll J, Owens L, Salih S, Meng R, Hammerschlag F. Response of transgenic Royal Gala apple (Malus x domestica Borkh.) shoots carrying a modified cecropin MB39 gene, to Erwinia amylovora. Plant Cell Rep 2001; 20: 306-12.

[55] Ottaviani MP, Hänisch ten Cate $\mathrm{ChH}$. Cotransformation and differential expression of introduced genes into potato (Solanum tuberosum L.) cv Bintje. Theor Appl Genet 1991; 81: 761-8.

[56] Barrell PJ, Lambie S, Reader JK, et al. In: O'Callaghan M, Jackson TA, Eds. Procedings of the $4^{\text {th }}$ International Workshop on Microbial Control of Soil Dwelling Pests, Targeting Resistance to Soil Dwelling Pests of Potatoes using Transgenic Technology. AgResearch, Lincoln, New Zealand; 1998; pp. 105-10.

[57] McMillan GP, Hedley D, Fyffe L, Pérombelon MCM. Potato resistance to soft-rot erwinias is related to cell wall pectin esterification. Physiol Mol Plant Pathol 1993; 42: 279-89.

[58] Pérombelon MCM, Kelman A. Blackleg and other potato diseases caused by soft rot Erwinias: proposal for revision of terminology. Plant Dis 1987; 71: 283-5.

[59] Conner AJ, Christey MC. Plant breeding and seed marketing options for the introduction of transgenic insect-resistant crops. Biocontrol Sci Tech 1994; 4: 463-73. 